\title{
PENGARUH KONSEP DIRI DAN KEMAMPUAN KOMUNIKASI INTERPERSONAL TERHADAP KEMAMPUAN BERPIKIR KRITIS MATEMATIKA
}

\author{
SEPNI YANTI \\ sepniyanti@gmail.com \\ Program Studi Teknik Informatika Fakultas Teknik, Matematika dan IPA \\ Universitas Indraprasta PGRI
}

\begin{abstract}
Abstrak. Tujuan penelitian ini adalah untuk menganalisis konsep diri dan kemampuan komunikasi interpersonal terhadap kemampuan berfikir kritis matematika. Metode yang digunakan dalam penelitian ini adalah metode survai. Subjek penelitian sebagai populasi seluruh siswa SMP Depok dengan populasi terjangkau siswa di SMP Negeri 8 dan SMP Mutiara Bangsa Depok dan sampel dipilih secara random 85 orang. Penelitian dilaksanakan mulai September hingga Desember 2014. Data yang digunakan diperoleh melalui teknik tes serta dianalisis menggunakan analisis kuantitatif dengan teknik analisis jalur. Dalam hal ini perhitungan hipotesis menggunakan SPSS 20.0. Hasil penelitian diperoleh: (1) Terdapat pengaruh langsung variabel konsep diri dengan terhadap kemampuan komunikasi interpersonal dengan nilai $t_{\text {hitung. }}=3,012$. (2) Terdapat pengaruh langsung konsep diri terhadap kemampuan berfikir kritis Matematika dengan nilai $\mathrm{t}_{\text {hitung }}=$ 2,482. (3) Terdapat pengaruh langsung negative kemampuan komunikasi interpersonal terhadap kemampuan berfikir kritis matematika dengan nilai $t_{\text {hitung }}=-1,308$ (4) Tidak terdapat Pengaruh Tidak Langsung konsep diri (X1) terhadap kemampuan berfikir kritis (Y) melalui kemampuan komunikasi interpersonal (X2) dengan berdasarkan nilai thitung $=0,148$. Implikasi dari penelitian ini antara lain: (1) Secara praktis penelitian ini dapat memberikan masukan kepada guru agar mengarahkan konsep diri dan komunikasi interpersonal siswa kea rah yang positif agar siswa dapat memiliki kemamapuan berfikir kritis matatika yang baik (2) Secara teoritis penelitian dapat menambah ilmu pengetahuan dalam pendidikan bagi institute maupun akademis dan mahasiswa.
\end{abstract}

Kata Kunci: Konsep Diri, Kemampuan Komunikasi Interpersonal, Kemampuan Berfikir Kritis Matematika

\section{PENDAHULUAN}

Matematika merupakan salah satu sarana untuk meningkatkan daya nalar siswa, karena didalam matematika terdapat berbagai macam perhitungan-perhitungan selogis (artinya: kemampuan berpikir seperti penjumlahan, pengurangan, pembagian dan perkalian dan juga dapat meningkatkan kemampuan dalam mengaplikasikan matematika). Untuk menghadapi tantangan hidup dalam memecahkan masalah karena dalam matematika siswa dilatih untuk dapat berpikir kritis (artinya: kemampuan berpikir untuk memecahkan berbagai masalah yang ditemui dengan analisis yang mendalam dan teliti), berpikir logis (artinya: kemampuan berpikir dengan lebih menggunakan akal budi dan perhitungan-perhitungan yang matang), berpikir sistematis (artinya: kemampuan berpikir secara bertahap dan berkesinambungan, mulai dari hal-hal yang sederhana sampai kompleks).

Banyak kendala yang di hadapai baik oleh guru matematika maupun oleh siswa itu sendiri dalam proses pembelajaran matematika salah satu kendala yang dihadapi oleh guru matematika antara lain adalah kurangnya kesiapan siswa untuk mengikuti pelajaran matematika, yang mungkin disebabkan oleh rendahnya konsep diri dan kurangnya 
kemampuan berpikir siswa dalam mempelajari matematika. Sehingga seorang guru untuk memilih cara berpikir yang efektif dan efisien dengan pokok bahasan tertentu. Maka makin banyak masalah yang timbul di kalangan siswa. Di antara masalah yang di timbulkan itu ialah kesulitan-kesulitan yang di alami didalam menerima atau menguasai pelajaran matematika. Kesulitan ini merupakan salah satu faktor penghambat dalam menempuh pelajaran selanjutnya.Agar tujuan tersebut tidak menyimpang, maka dilakukan evaluasi secara teratur dalam suatu kurun waktu tertentu. Evaluasi merupakan sebuah proses pengumpulan data untuk menentukan sejauh mana dalam hal apa, dan bagaiman tujuan pendidikan sudah tercapai. Jika belum, bagaimana yang belum dan apa sebabnya.

Kegiatan pembelajaran pada alasannya merupakan kegiatan komunikasi belajar. Guru dengan siswa terlibat dalam proses penyampaian pesan, penggunaan media, dan penerimaan pesan komunikasi dalam pembelajaran sangat menentukan hasil pembelajaran. Proses komunikasi yang berjalan secara lancar antara guru dengan siswa akan mendapatkan hasil pembelajaran yang baik. Persoalan kekurang pahaman dan persoalan lain yang berkaitan dengan materi dapat diselesaikan. Sebaliknya komunikasi yang terhambat bisa karena guru tidak membuka ruang komunikasi, guru kurang mampu menggali kemauan bertanya siswa, siswa takut bertany, dan sebab lainnya akan berimplikasi kurang bagus terhadap hasil pembelajaran. Proses komunikasi interpersonal seperti ini akan mendukung terciptanya suasana belajar yang konduktif, yaitu suasana yang interaktif dimana para siswa aktif terlibat didalamnya. Siswa tidak hanya diam mendapatkan ceramah dari guru tetapi siswa juga turut serta aktif dalam kegiatan belajar mengajar, misalnya dengan mengemukakan pendapat, bertanya, bertukar pikiran ataupun berdiskusi.Kemampuan berkomunikasi siswa tentunya berbeda-beda satu sama lain. Berangkat dari hal tersebut, maka pemilihan ini di angkat untuk mengetahui apakah ada hubungan efektivitas komunikasi interpersonal siswa dengan konsep diri. Dalam proses belajar mengajar matematika di sekolah, apabila seseorang memiliki konsep diri yang positif maka siswa tersebut akan memiliki kemampuan berpikir yang tinggi. Sebaliknya apabila seseorang memiliki konsep diri yang negatif maka siswa tersebut akan memiliki kemampuan berpikir yang rendah sehingga hasil belajar matematikanya pun rendah.

\section{TINJAUAN PUSTAKA}

\section{Kemampuan Berfikir Kritis Matematika}

Pengertian berpikir, berpikir merupakan manipulasi atau organisasi unsur-unsur lingkungan dengan menggunakan lambang-lambang sehingga tidak perlu langsung melakukan kegiatan yang tampak.Jadi berpikir menunjukkan berbagai kegiatan yang melibatkan penggunaan konsep dan lambang, sebagai pengganti objek dan peristiwa. Tahapan-tahapan dalam berpikir menurut Fankel dalam Rohmayasari, (2010:16) terdiri atas:

1) Tahap berpikir konvergen;

2) Tahap berpikir divergen;

3) Tahap berpikir kritis;

4) Tahap berpikir kreatif.

Ennis (dalam Williawati, 2009: 11) mengemukakan, "Definisi berpikir kritis adalah berpikir secara beralasan dan reflektif dengan menekankan pembuatan keputusan tentang apa yang harus dipercayai atau dilakukan”. Oleh karena itu, indikator kemampuan berpikir kritis dapat diturunkan dari aktivitas kritis siswa sebagai berikut:

1) Mencari pernyataan yang jelas dari setiap pertanyaan;

2) Mencari alasan;

3) Berusaha mengetahui informasi dengan baik; 
4) Memakai sumber yang memiliki kredibilitas dan menyebutkannya;

5) Memperhatikan situasi dan kondisi secara keseluruhan;

6) Berusaha tetap relevan dengan ide utama;

7) Mengingat kepentingan yang asli dan mendasar;

8) Mencari alternatif;

9) Bersikap dan berpikir terbuka;

10) Mengambil posisi ketika ada bukti yang cukup untuk melakukan sesuatu;

11) Mencari penjelasan sebanyak mungkin apabila memungkinkan;

12) Bersikap secara sistimatis dan teratur dengan bagian-bagian dari keseluruhan masalah.

Kemampuan berpikir kritis matematika adalah suatu proses penggunaan kemampuan berpikir secara efektif yang dapat membantu seseorang untuk membuat, mengevaluasi, serta mengambil keputusan tentang apa yang diyakini atau dilakukan yang bersifat logika. Kemampuan berpikir kritis matematika yang digunakan dalam penelitian ini mencakup:

1) Kemampuan mengidentifikasi asumsi yang diberikan;

2) Kemampuan merumuskan pokok-pokok permasalahan;

3) Kemampuan menentukan akibat dari suatu ketentuan yang diambil;

4) Kemampuan mengungkap data/definisi/teorema dalam menyelesaikan masalah;

\section{Konsep Diri}

Menurut Jalaludin Rakhmat (2012: 98) konsep diri adalah pandangan dan perasaan kita tentang diri kita. Presepsi tentang diri ini boleh bersifat psikologi, sosial, dan fisis. Jadi konsep diri bukan hanya sekedar gambaran deskriptif, tetapi juga penilaian kita tentang diri kita. Jadi, konsep diri meliputi apa yang kita pikirkan dan apa yang kita rasakan tentang diri kita. Dengan demikian, ada dua komponen konsep diri: komponen kognitif dan komponen efektif. Dalam psikologi sosial, komponen kognitif disebut citra diri (self image), dan komponen efektif disebut harga diri (self esteem). Keduanya, menurut William D.Brooks dan Philip Emmert (1976: 45), berpengaruh besar pada pola komunikasai interpersonal.

Faktor-faktor yang mempengaruhi konsep diri adalah:

1) Orang lain.

2) Anak belajar dari kehidupannya.

3) Kelompok rujukan.

Menurut M.farozin(2004:17) setiap macam konsep diri mempunyai aspek fisik dan psikologis. Aspek fisik terdiri dari konsep yang dimiliki individu tentang penampilannya, kesesuaian dengan seksnya, arti penting tubuhnya dimata orang lain. Aspek psikologis terdiri dari konsep individu tantang kemampuan dan ketidakmampuannya, harga dirinya, dan hubunganya dengan orang lain.

\section{Komunikasi Interpersonal}

Menurut suranto (2011: 5 ), "komunikasi interpersonal adalah proses penyampain dan penerimaan pesan antar pengirim pesan dan penerima pesan baik secara langsung maupun tidak langsung'”. komunikasi di katakana terjadi secara langsung apabila pihakpihak yang terlibat komunikasi dapat saling berbagi informasi tanpa melalui media sedangkan komunikasi tidak langsung menggunakan media tertentu.

Dalam komunikasi interpersonal ini masing-masing pihak yang terlibat dalam komunikasi langsung dapat merasakan dan mengetahui respon dari rekan komunikasi. Menurut Muhammad Budyatna (2011: 74), unsur-unsur komunikasi interpersonal adalah: 
1) Semua orang membutuhkan respon yang di inginkan dari pihak lain.

2) Data komunikator saling berlangsung antara satu dengan yang lainnya untuk mendapatkan respo.

3) Prosedur-prosedur kendali untuk mendapatkan jawaban-jawaban yang di inginkan di pelajari dalam situasi sosial penerimaannya bergantung kepada keberhasilan mereka dalam memperoleh jawab yang di inginkan\

4) Prilaku-prilaku dari orang yang mengendalikan dan memberi respon membentuk hubungan saling ketergantungan secara transaksional.

Dalam upaya meningkatkan komunikasi interpersonal di butuhkan banyak cara agar komunikasi interpersonal tercapai. Menurut Suranto (2011: 80) bahwa cara meningkatkan komunikasi interpersonal sebagai berikut:

1) Respect: menghargai setiap individu yang menjadi sasaran pesan yang kita sampaikan.

2) Simpati: kemampuan untuk menempatkan diri pada situasi atau kondisi yang di hadapi orang lain.

3) Clarity: bersifat terbuka atau transparansi.

4) Humble: sikap rendah hati

\section{METODE}

Metode penelitian yang dipakai adalah metode penelitian survey. Survai merupakan satu metode penelitian yang teknik pengambilan datanya dilakukan melalui pertanyaan tertulis atau lisan (Bailey, 1982) Sedangkan Desain penelitian yang digunakan dalam penelitian ini adalah analisis jalur. Menurut Supardi (2012:263) analisis jalur adalah suatu teknik pengembangan dari regresi linear berganda. Teknik ini digunakan untuk menguji besarnya sumbangan atau kontribusi yang ditunjukkan oleh koefisien jalurpada setiap diagram jalur dari hubungan kausal antar variabel $\mathrm{X}_{1}$ dan $\mathrm{X}_{2}$, terhadap $\mathrm{Y}$.

\section{HASIL DAN PEMBAHASAN}

Penelitian ini dilaksanakan pada kelas VIII SMP di Depok. Sedangkan objek penelitian dalam hal ini adalah siswa kelas VIII SMP Negeri 8 Depok dan SMP Mutiara Bangsa Depok tahun pelajaran 2014/2015 yang berjumlah 85 siswa. Data untuk kemampuan berpikir kritis matematika diambil dengan tes matematika bentuk esai dengan sebanyak 10 butir soal. Sedangkan data untuk konsep diri dan kemampuan komunikasi interpersonal diambil dengan kuesioner sebanyak 30 pernyataan.

Deskripsi data penelitian ini akan dikemukakan berbagai hasil penelitian dari data yang diperoleh. Pengelolaan data yang diperoleh dengan bantuan SPSS 20.0 dengan hasil sebagai berikut.

Tabel 1. Deskripsi Data Penelitian

\begin{tabular}{|c|c|c|c|c|}
\hline & $\begin{array}{l}\text { Konsep } \\
\text { Diri }\end{array}$ & $\begin{array}{l}\text { Kemampuan Komunikasi } \\
\text { Interpersonal }\end{array}$ & $\begin{array}{l}\text { Kemampuan Berfikir } \\
\text { Kritis Matematika }\end{array}$ \\
\hline \multirow[t]{2}{*}{$\mathrm{N}$} & Valid & 85 & 85 & 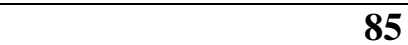 \\
\hline & Missing & $\mathbf{0}$ & $\mathbf{0}$ & $\mathbf{0}$ \\
\hline \multicolumn{2}{|c|}{ Mean } & 63.19 & 63.74 & 79.24 \\
\hline \multicolumn{2}{|c|}{ Median } & 63.00 & 63.00 & 80.00 \\
\hline \multicolumn{2}{|c|}{ Mode } & 67 & $63^{a}$ & 75 \\
\hline \multicolumn{2}{|c|}{ Std. Deviation } & 8.007 & 9.180 & 10.250 \\
\hline \multicolumn{2}{|c|}{ Variance } & 64.107 & 84.266 & 105.063 \\
\hline \multicolumn{2}{|c|}{ Minimum } & 46 & 40 & 60 \\
\hline \multicolumn{2}{|c|}{ Maximum } & 77 & 80 & 95 \\
\hline \multicolumn{2}{|c|}{ Sum } & 5371 & 5418 & 6735 \\
\hline
\end{tabular}

a. Multiple modes exist. The smallest value is shown 
Dari tabel 1 dapat dilihat bahwa nilai rata-rata dan median hampir sama, yaitu 63,19 dan 63 dapat disimpulkan bahwa data konsep diri dalam penelitian ini memiliki sebaran yang cenderung normal. Data kemampuan komunikasi interpersonal dalam penelitian ini memiliki sebaran yang cenderung normal karena nilai rata-rata dan median hampir sama, yaitu 63,74 dan 63. Dan Data kemampuan berfikir kritis matematika dalam penelitian ini memiliki sebaran yang cenderung normal karena nilai rata-rata dan median hampir sama, yaitu 79,24 dan 80.

Pada uji persyaratan normalitas, diperoleh bahwa semua sampel pada penelitian ini berdistribusi normal yang berarti sampel berasal dari populasi yang berdistribusi normal sehingga sampel telah mewakili karakteristik populasi. Sedangkan pada pengujian linieritas garis regresi, diperoleh bahwa garis regresi hubungan antara konsep diri dan kemampuan berfikir kritis matematika, garis regresi hubungan antara varibel kemampuan komunikasi interpersonal dan kemampuan berfikir kritis matematika, dan garis regresi hubungan antara konsep diri dan variabel kemampuan komunikasi interpersonal menghasilkan linier.

Dari Perhitungan statistik dengan bantuan program SPSS 20.0 diperoleh hasil seperti terlihat pada analisis jalur di bawah ini:

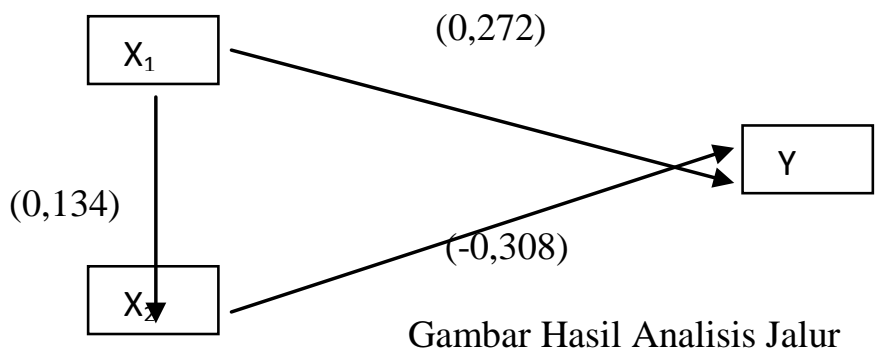

Keterangan:

$\mathrm{X}_{1}$ : Konsep Diri

$\mathrm{X}_{2}$ : Kemampuan Komunikasi Interpersonal

Y: Kemampuan Berfikir Kritis Matematika

1. Pengaruh Langsung Konsep Diri Terhadap Kemampuan Komunikasi Interpersonal.

Tabel 2. Rekapitulasi Hasil Perhitungan Persamaan Garis Regresi Pengaruh

Coefficients $^{\mathrm{a}}$ Variabel $\mathrm{X}_{1}$ terhadap $\mathrm{X}_{2}$

\begin{tabular}{|c|l|l|l|l|l|l|}
\hline \multicolumn{2}{|c|}{} & \multicolumn{2}{|l|}{$\begin{array}{l}\text { Unstandardized } \\
\text { Coefficients }\end{array}$} & \multicolumn{2}{l|}{$\begin{array}{l}\text { Standardized } \\
\text { Coefficients }\end{array}$} & \\
\cline { 3 - 7 } \multicolumn{2}{|c|}{ Model } & B & $\begin{array}{l}\text { Std. } \\
\text { Error }\end{array}$ & Beta & t & Sig. \\
\hline \multirow{3}{*}{1} & (Constant) & $\mathbf{4 0 . 9 9 9}$ & $\mathbf{7 . 6 1 0}$ & & $\mathbf{5 . 3 8 8}$ & $\mathbf{. 0 0 0}$ \\
\cline { 2 - 7 } & $\begin{array}{l}\text { Konsep } \\
\text { Diri }\end{array}$ & $\mathbf{. 3 6 0}$ & $\mathbf{. 1 1 9}$ & $\mathbf{. 3 1 4}$ & $\mathbf{3 . 0 1 2}$ & $\mathbf{. 0 0 3}$ \\
\hline
\end{tabular}

a. Dependent Variable: Kemampuan Komunikasi Interpersonal

Untuk pengujian hipotesis melalui analisis regresi dengan data angka baku diperoleh hasil perhitungan seperti pada Tabel 2 diperoleh persamaan regresi dengan data angka baku yang mempresentasikan pengaruh variabel $\mathrm{X}_{1}$ terhadap $\mathrm{X}_{2}, \mathrm{X}_{2}=0,314 \mathrm{X}_{1}$ 
Dari persamaan regresi di atas diperoleh koefisien regresi sama dengan koefisien jalur kemampuan komunikasi interpersonal konsep diri sebesar 0,314 memberikan pemahaman bahwa setiap penambahan satu satuan atau satu tingkatan konsep diri akan berdampak pada meningkatnya minat belajar matematika sebesar 0,314 satuan. Terlihat bahwa nilai Sig 0.03 dan $\mathrm{t}_{\text {hitung }}=3,012$, sedangkan ttabel $=1,989$. Karena nilai Sig $<0,05$ dan nilai $t_{\text {hitung }}>t_{\text {tabel }}$ maka Ho diterima yang berarti terdapat pengaruh langsung variabel konsep diri $\left(\mathrm{X}_{1}\right)$ terhadap kemampuan komunikasi interpersonal $\left(\mathrm{X}_{2}\right)$.

2. Pengaruh Langsung Konsep Diri Terhadap Kemampuan Berfikir Kritis Matematika

Tabel 3. Rekapitulasi Hasil Perhitungan Persamaan Garis Regresi Pengaruh Variabel $\mathrm{X}_{1}, \mathrm{X}_{2}$ terhadap $\mathrm{Y}$

Coefficients $^{\mathrm{a}}$

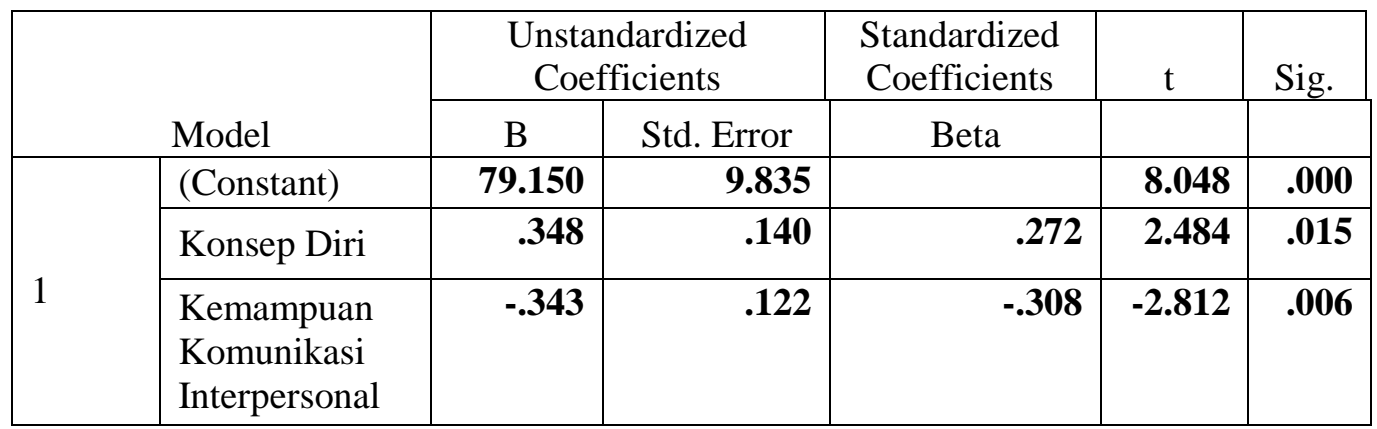

a. Dependent Variable: Kemampuan Berfikir Kritis Matematika

Untuk pengujian hipotesis melalui analisis regresi dengan data angka baku diperoleh hasil perhitungan seperti pada Tabel 3 diperoleh persamaan regresi dengan data angka baku yang mempresentasikan pengaruh variabel $\mathrm{X} 1, \mathrm{X} 2$, terhadap $\mathrm{Y}$

$\hat{\mathrm{Y}}=0,272 \mathrm{X}_{1}+(-0.308) \mathrm{X}_{2}$

Dari persamaan regresi di atas diperoleh koefisien regresi sama dengan koefisien jalur konsep diri sebesar 0,272 memberikan pemahaman bahwa setiap penambahan satu satuan atau satu tingkatan kemampuan numerik akan berdampak pada meningkatnya prestasi belajar matematika sebesar 0,272 satuan.

Terlihat bahwa nilai Sig 0.015 dan $\mathrm{t}_{\text {hitung }}=2,484$, sedangkan $\mathrm{t}_{\text {tabel }}=1.989$ Karena nilai Sig $<0,05$ dan nilai $t_{\text {hitung }}>t_{\text {tabel }}$ maka Ho ditolak yang berarti terdapat pengaruh langsung variabel konsep diri $\left(\mathrm{X}_{1}\right)$ terhadap kemampuan berfikir kritis matematika $(\mathrm{Y})$.

3. Pengaruh langsung kemampuan komunikasi interpersonal terhadap kemampuan berfikir kritis matematika

Selanjutnya uji signifikansi pengaruh dengan menentukan nilai ttabel dan pengujian hipotesis untuk $\alpha(=0.05)$ dan $\mathrm{dk}=. \mathrm{n}-\mathrm{k}-1$. Untuk pengujian hipotesis melalui analisis jalur diperoleh hasil perhitungan seperti pada Tabel 3 diperoleh persamaan regresi dengan data angka baku yang mempresentasikan pengaruh variabel $\mathrm{X} 1, \mathrm{X} 2$, terhadap $\mathrm{Y}$

$\hat{\mathrm{Y}}=0,272 \mathrm{X}_{1}+(-0,308) \mathrm{X}_{2}$

Dari persamaan regresi di atas diperoleh koefisien regresi sama dengan koefisien jalur minat belajar matmatika sebesar -0,308 memberikan pemahaman bahwa setiap penambahan satu satuan atau satu tingkatan kemampuan komunikasi interpersonal akan berdampak pada meningkatnya kemampuan berfikir kritis matematika sebesar $-0,308$ satuan.

Terlihat bahwa nilai Sig 0.006 dan $t_{\text {hitung }}=-2,812$, sedangkan $t_{\text {tabel }}=1,989$. Karena nilai Sig $<0,05$ dan nilai $t_{\text {hitung }}>t_{\text {tabel }}$ maka Ho ditolak yang berarti terdapat pengaruh 
langsung negatif variabel kemampuan komunikasi interpersonal ( $\left.\mathrm{X}_{2}\right)$ terhadap kemampuan berfikir kritis matematika (Y).

4. Pengaruh Tidak Langsung konsep diri terhadap kemampuan berfikir kritis Matematika melalui komunikasi interpersonal. Selanjutnya uji signifikansi pengaruh dengan menentukan nilai ttabel dan pengujian hipotesis untuk $\alpha(=0.05)$ dan $\mathrm{dk}=. \mathrm{n}-\mathrm{k}-1$. Untuk menghitung nilai t pada pengujian hipotesis dengan menggunakan Ms Exel maka didapatkan (Penghitungan bisa dilihat pada Lampiran):

$$
\begin{aligned}
& \text { P321 = P21 x P32 } \\
& \begin{aligned}
\text { P321 = 0,314 } \times(-0,308)=-0,097 \\
\text { Thitung = th }=\frac{P 321}{S g} \\
\text { Dengan Sg }= \\
=\frac{\sqrt{(n 21-1) S_{21} 2+(n 32-1) S_{32} 2}}{(n 21+n 32-2)} \\
=\frac{\sqrt{(85-1) 0,119+(85-1) 0,122}}{(85+85-2)} \\
=\frac{\sqrt{9,996+10,248}}{168} \\
=0,027
\end{aligned}
\end{aligned}
$$

Sehingga didapatkan:

$$
\begin{aligned}
\text { Thitung }=\text { th } & =\frac{P 321}{S g} \\
& =\frac{-0,097}{0,027} \\
& =-3,582
\end{aligned}
$$

Karena $t_{\text {hitung }}(3,582)>t_{\text {tabel }}(1,989)$ maka Ho ditolak yang berarti terdapat pengaruh tidak langsung antara konsep diri $\left(\mathrm{X}_{1}\right)$ terhadap kemampuan berfikir kritis matematika $(\mathrm{Y})$ melalui kemampuan komunikasi interpersonal $\left(\mathrm{X}_{2}\right)$.

\section{PENUTUP}

\section{Simpulan}

1. Terdapat pengaruh langsung variabel konsep diri $\left(\mathrm{X}_{1}\right)$ dengan terhadap kemampuan komunikasi interpersonal $\left(\mathrm{X}_{2}\right)$ siswa SMP Depok.

2. Terdapat pengaruh langsung konsep diri $\left(\mathrm{X}_{1}\right)$ terhadap kemampuan berfikir kritis Matematika (Y) siswa SMP Depok.

3. Terdapat pengaruh langsung negative kemampuan komunikasi interpersonal (X2) terhadap kemampuan berfikir kritis matematika (Y) siswa SMP Depok.

4. Tidak terdapat Pengaruh Tidak Langsung konsep diri (X1) terhadap kemampuan berfikir kritis (Y) melalui kemampuan komunikasi interpersonal (X2) siswa SMP Depok.

\section{Saran}

1. Banyak hal yang dapat meningkatkan kemampuan berfikir kritis matematika siswa dalam pembelajaran yang dilakukan di dalam kelas, diantaranya dengan meningkatkan konsep diri dalam diri siswa dan dalam mengahadapi berbagai persoalan. Peningkatan konsep diri ini dapat membantu siswa dalam meningkatkan kemampuan berfikir kritis matematika. Hal ini dibuktikan dengan hasil penelitian di atas. Oleh karena itu, untuk meningkatkan kemampuan berfikir kritis matematika siswa yang baik, hendaknya guru dapat meningkatkan kemampuan komunikasi interpersonal siswanya. 
2. Faktor lain yang dapat meningkatkan kemampuan berfikir kritis matematika siswa adalah dengan meningkatkan kemampuan komunikasi interpersonal siswa sehingga kemampuan berfikir kritis matematika siswa dapat meningkat.

3. Guru hendaknya selalu membimbing siswa agar memiliki konsep diri dan kemampuan komunikasi interpersonal kearah yang positif agar siswa memiliki kemampuan berfikir kritis matematika yang baik.

\section{DAFTAR PUSTAKA}

A.W, Suranto. 2011. Komunikasi Interpersonal. Yogyakarta: Graha Ilmu. Ennis. 2009. Critical Thinking Test. USA: Bright Minds.

Farozin Muhammad. 2004. Pemahaman Tingkah Laku. Jakarta: PT.Asdi Mahasatya Rakhmat, Jalalidin. 2012. Psikologi Komunikasi. Bandung: Remaja Rosdakarya.

Supardi. 2013. Aplikasi Statistika Dalam Penelitian. Jakarta: PT. Change Publication. Suparman I. A. 2013. Aplikasi Komputer Dalam Penyusunan Karya Ilmiah. Tangerang: PT. Pustaka Mandiri. 